- Currently a small proportion of SHOs are involved in undergraduate supervision.

- $65 \%$ of those SHOs not involved in undergraduate supervision would value this experience as part of their training.

- 56\% of undergraduates were comfortable with an SHO supervising them.

- Both undergraduates and SHOs feel that SHOs would benefit from some form of training in teaching/supervising undergraduates.

\title{
An investigation of the acceptability of undergraduate supervision by Senior House Officers and General Professional Trainees
}

\author{
J. Leitch ${ }^{1}$ and F. Soldani ${ }^{2}$
}

\begin{abstract}
Aim: This study assessed whether Senior House Officers (SHO)/General Professional Trainees (GPT) are, or would be, comfortable supervising clinical undergraduates, whether they find this to be a valuable experience within their training programme, and whether undergraduates are or would be comfortable with SHO/GPTs supervising them.

Method: Questionnaires were distributed to fourth and final year students at Glasgow and Dundee Dental Schools and fourth year students at Newcastle Dental School. Questionnaires were also distributed to SHO/GPTs at Glasgow Dental Hospital and School and Edinburgh Dental Institute.

Results: Seventy-nine per cent of respondent SHO/GPTs were currently not involved in the supervision of undergraduates within their present rotation, 65\% of whom stated that they would value the experience of this within their training. Of those involved in supervision, 83\% found the experience valuable. Forty-four per cent of students were unsure or not comfortable with SHO/GPTs supervising within an oral surgery department and approximately the same in other departments. Twentyeight per cent of respondents felt that university lecturers should be the main trainer.
\end{abstract}

Conclusion: SHO/GPTs value supervising undergraduates as part of their training experience. More than half of students are comfortable with SHO/GPTs supervising them. Both groups suggest that SHO/GPTs should receive some form of training in teaching prior to supervising undergraduates.

\section{INTRODUCTION}

With the arrival of Continuing Professional Development, it has become clear to newly qualified graduates that the cycle of training in our profession is a never ending one. After five undergraduate years and attaining their degree they must immediately begin on the continuous path of lifelong learning. With this in mind, at what point does the 'trainee' have the knowledge to become the 'trainer'? When is their knowledge adequate enough to pass it on

\footnotetext{
${ }^{1 *}$ Clinical Lecturer, Glasgow Dental Hospital and School, 378 Sauchiehall Street, Glasgow, G2 3JZ; ${ }^{2}$ Senior House Officer, Glasgow Dental Hospital and School, 378

Sauchiehall Street, Glasgow, G2 3JZ

${ }^{*}$ Correspondence to: Dr Jason Leitch

Email: leitch@bigfoot.com
}

\section{Refereed Paper}

Received 06.01.04; Accepted 15.06.04

doi: $10.1038 /$ sj.bdj.4812417

$\odot$ British Dental Journal 2005; 198: 771-775 to those on a lower rung of the ladder than themselves?

In the Scottish Centre for Postgraduate Medical and Dental Education's (SCPMDE) Evaluation Of General Professional Training (GPT), ${ }^{1}$ consultants favoured young House Officers working alongside GPTs with six months experience in Community Dental Services per year in General Dental Services. This mixture of talent and skills was perceived as an advantage, allowing trainees at different stages of their education with different experiences to learn from one another. By extrapolation, is it also then advantageous for undergraduates to be supervised by Senior House Officers (SHOs)? For ease of understanding, SHO refers to Senior House Officers and General Professional Trainees throughout the rest of the text.

Neither in the above publication nor in the General Dental Council's The next two years $^{2}$ is there any mention of Senior House Officers' involvement in undergraduates' supervision. Newly qualified dentists are of course qualified and believe that they have proved themselves at undergraduate level to the extent that no written exams are required after qualification to prove this. ${ }^{1}$ More recent research has argued the case for a 'competence based model' of assessment of SHOs. ${ }^{3}$ Nonetheless, are SHOs qualified enough to oversee undergraduates and potentially influence their educational experience? At the same time there is evidence that SHOs are competing with undergraduates for clinical cases as well as resources. ${ }^{1}$

Actual clinical experience is ranked as one of the most useful experiences in hospital training; ${ }^{4}$ therefore, should an SHO's time be spent in supervising simple procedures rather than undertaking more complicated procedures on their own patients? 
The SHO post may be seen as an apprenticeship towards a hospital career, which is the traditional model for medical education. ${ }^{5}$ It may be argued then, that since consultants and other career grade staff must develop their role as educators, ${ }^{4}$ it is appropriate that SHOs also experience this as part of their apprenticeship. If this is the case, should SHO supervision of undergraduates be made a formal part of the SHO training experience in all departments?

When looking at this issue, the controversial view of an $\mathrm{SHO}$ as a 'dogsbody' 6 must be considered. Is the delegation of duty, of supervision of undergraduates performing simple techniques inappropriate use of junior staff resources? Or is this hierarchical supervision strategy perfectly acceptable and viewed by SHOs as a valuable training experience. After all, Specialist Registrars are used in the same way to oversee SHO work.

Inevitably, there is not the finance for every undergraduate to be supervised by a senior member of staff, but at the same time it appears that hospital trainees would like more dedicated time with their own trainers. ${ }^{7}$ Are SHOs spending excessive time supervising undergraduates, instead of more learner-centred training and protected study time, ${ }^{7}$ or is the training experience varied and are SHOs stimulated by undergraduate questioning?

It has been suggested that effective training posts have four key elements: ${ }^{5}$

1) Regular appraisal with an identified educational supervisor.

2) Workplace learning in which the trainee is guided through new ways of handling clinical/organisational problems.

3) Formal education.
4) Study leave.

The aims of this research project are:

1) Are or would undergraduates and SHOs be comfortable with SHOs supervising undergraduates?

2) Is SHO supervision of undergraduates perceived by SHOs as valuable in their training?

3) Identify who SHOs and undergraduates feel their main trainer should be.

\section{MATERIALS AND METHODS}

This study was designed to determine whether or not SHOs and students are, or would be, comfortable with SHO supervision of undergraduates. Pilot study questionnaires were distributed to 20 students with a $100 \%$ response rate. The questionnaire was subsequently redrafted as appropriate, and consisted of seven questions (Fig. 1). Thereafter, questionnaires were distributed to all clinical year dental students in Glasgow and Dundee and fourth year students in Newcastle.

Questionnaires were distributed to SHOs in Glasgow and Edinburgh (Fig. 2). GPTs based within the hospital service were also included. Again, a pilot study of four SHOs was carried out and the questions redrafted accordingly.

\section{RESULTS}

\section{Student questionnaire results}

Two hundred and seven questionnaires were returned - a 70\% response rate. $81 \%$ of clinical students are aware of staff title and its rank within the hospital system, and therefore acknowledge that SHOs are the most junior of hospital staff members. 95\% of final years are aware of staff title compared to $74 \%$ of fourth years. $71 \%$ of all students usually know the level of staff supervision; 11\% always know the level of staff supervising them. With regard to the confidence that clinical students have in SHOs' skills, 73\% were confident and 16\% have little confidence in SHOs supervising them (Table 1). 56\% of clinical students would agree that dentists with one-year post qualification experience are appropriate for clinical supervision in oral surgery. The remaining 44\% are either unsure or not comfortable with this situation (Table 2). 56\% are happy with SHOs supervising them in departments other than oral surgery (Table 3). Students were asked to rank the important attributes of the person supervising them. $47 \%$ elected that the age of the supervising clinician was the least important attribute (graded 4 or 5 on a five point scale). The most important attributes were communication skills of the supervisor (35\%) and the number of years of clinical experience (35\%) (Table 4).

\section{SHO questionnaire results}

Twenty-nine questionnaires were returned - a 58\% response rate. Year of qualification varied between 1990 and 2002, with $45 \%$ having graduated in 2001 . The period of time working as an SHO was from one month to two years eight months. 69\% of respondents were in GPT posts. There was representation of all specialties including community dentistry and oral and maxillofacial surgery. $79 \%$ were not involved in supervising undergraduates. The remaining six SHOs were based in conservation (two), oral surgery (two), oral medicine (one) and child dental care/orthodontics (one). 39\% of those not currently supervising students had previous experience of supervising undergraduates. $74 \%$ of those not currently involved

\begin{tabular}{|c|c|c|c|}
\hline \multicolumn{4}{|c|}{ Fig. 1 Questionnaire to students } \\
\hline 1) What year are you in? & $\begin{array}{l}\text { 2) Please rank the following staff titles. } \\
\text { ( } 1 \text { being the most experienced, } 4 \text { being } \\
\text { the least experienced. ) }\end{array}$ & $\begin{array}{l}\text { 3) How often do you know the level } \\
\text { of the member of staff supervising you }\end{array}$ & $\begin{array}{l}\text { 4) You are being supervised by a } \\
\text { member of staff who qualified one } \\
\text { year ago. How confident are you in } \\
\text { their skills? }\end{array}$ \\
\hline Fourth year & Senior House Officer & Always & Very confident \\
\hline \multirow[t]{3}{*}{ Final year } & Consultant & Usually & Confident \\
\hline & Associate Specialist & Seldom & Little confidence \\
\hline & Staff Grade & Never & No confidence at all \\
\hline \multicolumn{2}{|l|}{$\begin{array}{l}\text { 5) Do you think a dentist who } \\
\text { qualified one year ago should } \\
\text { supervise you in the oral sugery } \\
\text { department? }\end{array}$} & $\begin{array}{l}\text { 7) With regard to your 'Trainer', rank } \\
\text { the following in order of importance } \\
\text { to you. ( } 1 \text { being the most important, } \\
5 \text { being the least important.) }\end{array}$ & $\begin{array}{l}\text { 8) Do you have any other comments } \\
\text { with regard to the issues raised } \\
\text { above? }\end{array}$ \\
\hline$\overline{Y e s}$ & Yes & Mature age & \\
\hline No & No & Position of seniority within hospital & \\
\hline \multirow[t]{5}{*}{ Unsure } & Unsure & \multirow{2}{*}{$\begin{array}{l}\text { Number of years of clinical } \\
\text { experience }\end{array}$} & \\
\hline & & & \\
\hline & & \multirow{2}{*}{$\begin{array}{l}\text { Number of years of teaching } \\
\text { experience }\end{array}$} & \\
\hline & & & \\
\hline & & Good communication skills & \\
\hline
\end{tabular}


in supervising undergraduates would feel comfortable supervising them, and 65\% would value the experience as part of their training. Half of those SHOs currently involved in supervision of undergraduates had previous experience of this; they all felt very comfortable or comfortable supervising undergraduates. 83\% of those supervising found the experience very valuable or valuable. Supervising SHOs found that patient treatment sessions were the most valuable training experience, while undergraduate supervision was the least valuable (Table 5). 10-25\% of their time was spent supervising undergraduates, and $67 \%$ of SHOs seldom required assistance from a senior member of staff while supervising undergraduates. 38\% of all respondents felt that consultants should be the main trainer of SHOs and $28 \%$ that the main trainer of undergraduates should be a university lecturer.

\section{DISCUSSION}

Although $73 \%$ of students are confident in SHOs' skills, there were still $16 \%$ who had little confidence in SHO skills. If there is doubt in a teacher's skills then this may have a negative effect on the student's training and education. 56\% of students were comfortable with a one-year postqualified dentist supervising them in oral surgery. In theory, this is the minimum amount of post qualification experience for an SHO to have attained. The remaining $44 \%$ were either unsure or did not feel comfortable with this situation. In one of the units involved in this study (Glasgow) SHOs regularly supervise undergraduates doing simple and surgical extractions.

The age of the supervising clinician was deemed the least important factor in suitability for supervision. This is an important point to note as often older SHOs may only have the same amount of experience as a younger colleague having qualified at the same time. Combining this with the position of seniority being the second least important attribute, it is apparent that age and position are not important in the eyes of students with regard to the person supervising them.

Communication skills of the supervising clinician were deemed the most important, with 69\% ranking this highly. Obviously the professional relationship between student and supervisor is subject to both personalities. Also, different students will prefer different types of teaching methods and therefore the same supervisor will not be universally popular with all students.

In one institution, no distinction is made between Junior House Officer, Senior House Officer and General Professional Trainee, all having the title SHO. All

Table 1 You are being supervised by a member of staff who qualified one year ago. How confident are you in their skills?

\begin{tabular}{llll}
\hline & Fourth year & Final year & Total \\
\hline Very confident & $17(12 \%)$ & $2(3 \%)$ & $19(9 \%)$ \\
\hline Confident & $106(74 \%)$ & $46(72 \%)$ & $152(73 \%)$ \\
\hline Little Confidence & $19(13 \%)$ & $15(23 \%)$ & $34(16 \%)$ \\
\hline No Confidence & $1(0 \%)$ & $1(2 \%)$ & $2(3 \%)$
\end{tabular}

Table 2 Do you think a dentist who qualified one year ago should supervise you in the oral surgery
department?
\begin{tabular}{llll}
\hline & Fourth year & Final year & Total \\
\hline Yes & $74(52 \%)$ & $42(66 \%)$ & $116(56 \%)$ \\
\hline No & $30(21 \%)$ & $10(16 \%)$ & $40(19 \%)$ \\
\hline Unsure & $39(27 \%)$ & $12(19 \%)$ & $51(25 \%)$
\end{tabular}

Table 3 Do you think a dentist who qualified one year ago should supervise you in departments other
than oral surgery?
\begin{tabular}{llll}
\hline & Fourth year & Final year & Total \\
\hline Yes & $79(55 \%)$ & $36(56 \%)$ & $115(56 \%)$ \\
\hline No & $26(18 \%)$ & $16(25 \%)$ & $42(20 \%)$ \\
\hline Unsure & $38(27 \%)$ & $12(19 \%)$ & $50(24 \%)$
\end{tabular}

\begin{tabular}{|c|c|c|}
\hline & $\begin{array}{l}\text { Total figures ranked } \\
1 \text { or } 2\end{array}$ & $\begin{array}{l}\text { Total figures ranked } \\
4 \text { or } 5\end{array}$ \\
\hline Mature age & $9(2 \%)$ & $194(47 \%)$ \\
\hline Position of seniority & $24(6 \%)$ & $161(39 \%)$ \\
\hline No. of years' clinical experience & $145(35 \%)$ & $12(3 \%)$ \\
\hline No. of years' teaching & $93(23 \%)$ & $24(6 \%)$ \\
\hline Good communication skills & $143(35 \%)$ & $23(26 \%)$ \\
\hline
\end{tabular}

\begin{tabular}{|c|c|c|c|c|c|c|c|}
\hline & 1 & 2 & 3 & 4 & 5 & 6 & 7 \\
\hline Patient treatment sessions & 5 & 1 & 0 & 0 & 0 & 0 & 0 \\
\hline Consultant clinics & 2 & 2 & 2 & 0 & 0 & 0 & 0 \\
\hline Accident and Emergency & 0 & 2 & 0 & 2 & 0 & 1 & 0 \\
\hline Tutorials & 0 & 2 & 1 & 0 & 2 & 0 & 0 \\
\hline Undergraduate supervision & 0 & 0 & 0 & 0 & 3 & 1 & 1 \\
\hline Outside hospital placements & 1 & 0 & 1 & 0 & 1 & 2 & 1 \\
\hline
\end{tabular}

have different or no hospital experience, but all carry out the same student supervisory role, some requiring more help from senior staff than others. Students were asked if they had any other views. These varied considerably:

- Some of the SHOs have a little attitude as they are no longer students any more. A little more humility would be appreciated.'

- 'Turns out SHOs have less respect for undergraduates than consultants. WHY?'

Some were more positive:

- 'Often, young dentists are good at explaining things and make you feel less intimidated:

- 'Good to see SHOs in supervising roles as it gives you an idea of what will be expected of you when you get to their level. Good to see that they are not always certain and that they can ask their supervisors questions, and also that they are constantly learning. Makes students feel approaching them is a lot easier, especially with questions they may not want to ask more senior staff',

- 'Depends on personality and skills of trainer rather than age or years qualified, as GDPs who work on clinics often have less knowledge of up-to-date practices than those newly qualified.'

-I feel that they (SHOs) cover the basics the best and cover gaps in knowledge that some other more experienced clinicians take for granted that we know, which often we don't'

-As long as the tutor has been given adequate teacher training then this should be fine.' 


\section{EDUCATION}

\begin{tabular}{|c|c|c|c|c|}
\hline \multicolumn{5}{|c|}{ Fig. 2 Senior House Officer Questionnaire } \\
\hline \multicolumn{5}{|l|}{ Section 1} \\
\hline \multirow[t]{5}{*}{$\begin{array}{l}\text { 1) In what year did you } \\
\text { qualify? }\end{array}$} & $\begin{array}{l}\text { 2) For what period of time have } \\
\text { you worked as an } \mathrm{SHO} \text { ? }\end{array}$ & $\begin{array}{l}\text { 3) What department are you } \\
\text { currently working in? }\end{array}$ & 4) Is the post part of GPT? & $\begin{array}{l}\text { 5) In your current post are } \\
\text { you involved in supervising } \\
\text { undergraduates? }\end{array}$ \\
\hline & Years & & Yes & Yes \\
\hline & Months & & No & No \\
\hline & & & & $\begin{array}{l}\text { If no to the above question, } \\
\text { please go to Section } 2 \text {. }\end{array}$ \\
\hline & & & & $\begin{array}{l}\text { If yes to the above question, } \\
\text { please go to Section } 3 \text {. }\end{array}$ \\
\hline
\end{tabular}

\section{Section 2}

\begin{tabular}{|c|c|c|c|c|c|}
\hline $\begin{array}{l}\text { 1) Did you have any previous } \\
\text { experience of supervising } \\
\text { undergraduates prior to } \\
\text { your present post? }\end{array}$ & \multicolumn{2}{|c|}{$\begin{array}{l}\text { 2) Would you feel comfortable } \\
\text { supervising undergraduates in } \\
\text { your current post? }\end{array}$} & \multicolumn{2}{|c|}{$\begin{array}{l}\text { 3) Do you feel that supervising } \\
\text { undergraduates would be a } \\
\text { valuable part of your training } \\
\text { experience? }\end{array}$} & Please go to Section 4. \\
\hline Yes & Yes & Unsure & Yes & Unsure & \\
\hline No & No & & No & & \\
\hline
\end{tabular}

\section{Section 3}

\begin{tabular}{|c|c|c|c|}
\hline \multirow[t]{2}{*}{$\begin{array}{l}\text { 1) Did you have any previous } \\
\text { experience of supervising } \\
\text { undergraduates prior to your } \\
\text { present post? } \\
\text { Yes }\end{array}$} & $\begin{array}{l}\text { 2) How comfortable do you feel } \\
\text { supervising undergraduates? }\end{array}$ & $\begin{array}{l}\text { 3) Do you feel supervising } \\
\text { undergraduates is a valuable } \\
\text { part of your training } \\
\text { experience? }\end{array}$ & $\begin{array}{l}\text { 4) Where do you feel you gain most } \\
\text { valuable training experience? } \\
\text { Please rank from } 1=\text { most valuable, } \\
\text { to } 7=\text { least valuable. }\end{array}$ \\
\hline & Very comfortable & Very valuable & Patient Treatment Sessions \\
\hline \multirow[t]{6}{*}{ No } & Comfortable & Valuable & Consultant Clinic \\
\hline & Uncomfortable & Not valuable at all & Accident and Emergency Clinic \\
\hline & Very uncomfortable & Indifferent & Tutorials \\
\hline & & & Undergraduate Supervision \\
\hline & & & Outside Hospital Placement \\
\hline & & & Other. Please specify \\
\hline
\end{tabular}

5) During an average week, what percentageof your time is spent directly supervising undergraduates?

\begin{tabular}{rl|l|l|l}
\hline$\%$ & Very Often & Often & & \\
\hline Seldom & Never & & \\
\hline
\end{tabular}

\section{Section 4}

$\begin{aligned} & \text { 1)Who do you feel should be the } \\
& \text { main trainer of SHO's? }\end{aligned}$
\begin{tabular}{l|l|l|l|l|l} 
Staff Grade & University Lecturer & Staff Grade & Consultant & & $\begin{array}{l}\text { 3) Do you have any other comments } \\
\text { with regard to the issues raised } \\
\text { above? }\end{array}$ \\
\hline Associate Specialist & Consultant & Associate Specialist & Specialist Registrar & \\
\hline Visiting GP & Specialist Registrar & Visiting GP & SHO & \\
\hline
\end{tabular}

-I don't mind being supervised by someone with less experience, but I feel I should be taught by someone with teaching experience. I am confident in their clinical skills, but not in their teaching skills and would disregard a teaching point made by them.'

Of those SHOs responding who were currently supervising undergraduates, all felt very comfortable or comfortable with this. Although the majority (83\%) value this experience they do not rank it highly compared with other parts of their training, with consultant clinics being the second most highly valued - which corresponds with their opinion that consultants should be their main trainer. Patient treatment sessions were most highly ranked, which agrees with previous papers. ${ }^{4}$ The time spent by those currently supervising undergraduates varied between 10-25\%, which would equal a minimum of one session per week. Those not supervising undergraduates at present generally would feel comfortable and would value supervising undergraduates, suggesting that formal introduction of this into SHO timetables for a controlled proportion of their time would be generally welcomed. This highlights the variability between SHO posts and differences in experience gained. Undergraduate supervision would help them gain experience in teaching, which is part of higher specialist training. ${ }^{8}$ 
Comments from SHOs correspond to those from students suggesting training for SHOs in teaching prior to supervising undergraduates. Other comments included: 'I think supervising undergraduates gives you an opportunity to be always prepared to answer questions which is also helpful in your own personal development' - thus confirming that it can be seen as valuable in SHO training. Perhaps inclusion of a teaching skills course within the SHO induction could be introduced to facilitate this.

\section{CONCLUSION}

In response to the aims stated for this paper, and from the small numbers, preliminary conclusions suggest that SHOs are, and would be, comfortable with supervising clinical undergraduates and would find the experience valuable, but only for limited periods of time. 56\% of students would be comfortable with this. Secondly, SHOs would, or do, find it valuable and therefore it would be a valuable part of their training.

In response to it being a suitable use of staff resources, it could be argued that since it would be a valuable part of training, it would also be "part of handling clinical/organisational problems within a hospital environment. ${ }^{5}$ Both SHOs and undergraduates themselves would appreciate SHO training in teaching/supervision of undergraduates.

Sincere gratitude to Julie Murray for analysis of SHO data. Thank you also to Dr Kathy Harley, Dr Angus Pringle and Jenni Garden.

1. Scottish Council for Research in Education. A bridge to the future: An evaluation of general professional training in Scotland. Scottish Council for
Postgraduate Medical and Dental Education, 1999.

2. General Dental Council. The next two years -

General professional training. London: GDC, 1998

3. Bullock A D, Butterfield S, Morris Z S, Frame J W Recommendations for improving the assessment of postgraduate dental education. Br Dent J 2002; 192: 407-410.

4. Centre for Medical Education, Dundee, Scottish Council for Research in Education. The early years of postgraduate dental training in England, a consultation document. London: Standing Committee on Postgraduate Medical and Dental Education, 1995.

5. Hayden J. Improving SHO Experience. Med Educ 1999; 33: 402-403.

6. Clark J D, Thomas M, Robertson L. A novel approach to promoting change in $\mathrm{SHO}$ training in a dental teaching hospital. Br Dent J 2002; 193: 167-171.

7. Plowman L, Musselbrook K. An evaluation of general professional training for dentistry in Scotland.

BrDent J 2000: 188: 563-567.

8. Frame J W, Bullock A D, Butterfield S, Morris ZS Belfield C R. An evaluation of the assessment of post-registration dental education (final report). Birmingham: University of Birmingham, 1999. 